ERDA/NASA/1022-77/16

NASA TM 73702

\title{
TERRESTRIAL \\ PHOTOVOLTAIC \\ MEASUREMENT \\ PROCEDURES
}

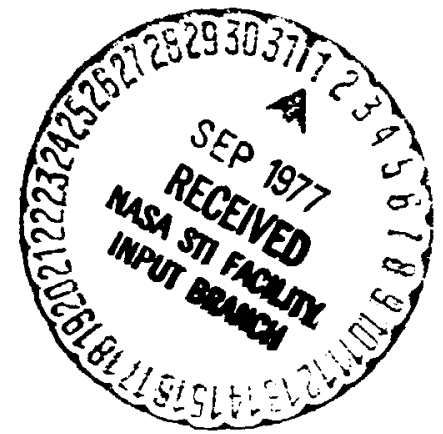

National Aeronautics and Space Administration Lewis Research Center

Cleveland, Ohio 44135

June 1977

(RASA-TM-737C2) TERBESTRIAL EHOTOVOLTAIC
MEASUBEAENT EBOCECUBES (BASA) 18 P HC
A02/ME O01

N77-29603

Unclas

G3/44 40844

Prepared for

ENERGY RESEARCH AND

DEVELOPMENT ADMINISTRATION

Office of the Assistant Administrator for

Solar, Geothermal, and Advanced Energy Systems Division of Solar Energy

Under Interagency Agreement E(49-26)-1022 


\section{PREFACE}

The second ERDA/NASA Photovoltaic Measurements Workshop was held in Baton Rouge, Louisiana, in November 1976. Nearly sixty people attended from all segments of the solar cell community. The Workshop was divided into three sessions, each lasting one day:

(1) Terrestrial Solar Irradiance

(2) Solar Simulation and Reference Cell Calibration

(3) Cell and Array Measurement Procedures

For each session several short papers were presented in the morning. The attendees then discussea key questions in two or three workshop groups in the afternoon.

This \& eport presents the revised measurement procedures that resulted from this Workshop; these procedures replace the "Interim Solar Cell Testing Procedures for Terrestrial Applications" published in July 1975.

A program committee was established to help plan the Workshop and write the procedures. The assistance of the following people is greatly appreciated:

Eldon Boes

Edmund Conway

Henry Curtis

Gilbert Do"'ning

Jon Geist

John Hickey

Frederick Koomanoff

John Meakin

Eugene Ralph

Michael Riches

Donald Schueler

Roger Van Overstraeten

Douglas Warschauer
Sandia Laboratory

NASA Langley Research Center

NASA Lewis Research Center

Jet Propulsion Laboratory

National Bureau of Standards

Eppley Laboratory

Energy Research and Develupment Administration University of Delaware

Spectrolab, Inc.

Energy Research and Development Administration

Sandia Laboratory

Commission of European Communities

Energy Research and Development Administration

Henry W. Erandhorst, Jr. , Chairman

Head, Photovnltaic Research and Technology Section

NASA Lewis Rusearch Center 



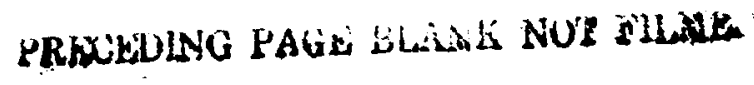

CONTENTS

Page

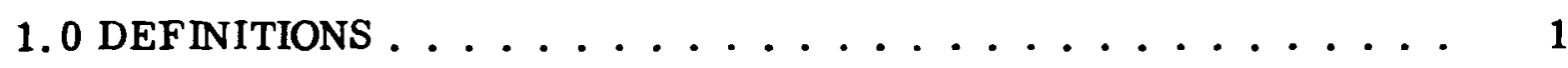

2.0 NATURAL SUNLIGHT MEASURE MENT PROCEDURES . . . . . . 3

2.1 Measurement Equipment . . . . . . . . . . . . 3

2.2 Measurement Procedures . . . . . . . . . . 4

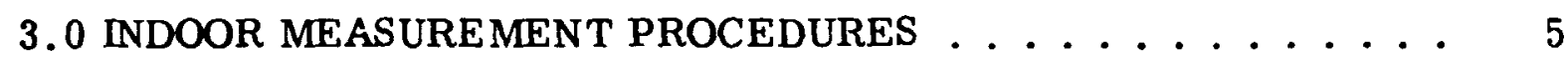

3.1 Measurement Equipment . . . . . . . . . . 5

3.2 Measurement Procedures . . . . . . . . . . 6

4.0 CONCENTRATOR SYSTEM MEASUREMENTS PROCEDURES . . . 6

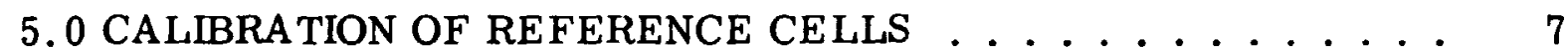

5.1 Measurement Equipment . . . . . . . . . . 7

5.2 Calibration Procedures $\ldots \ldots \ldots \ldots$

6.0 SOLAR SIMULATION AND COMMON TEST EQUIPMENT . . . . . 9

6. 1 Solar Simulator for Photovoltaic Measurements . . . . . . 9

6.2 Common Test Equipment. . . . . . . . . . . 10

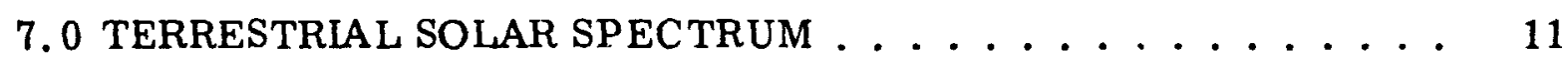

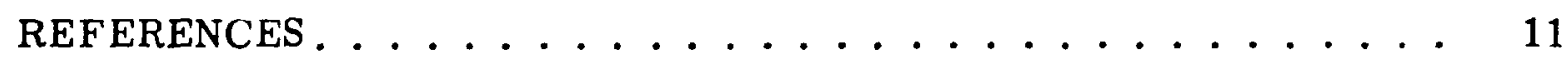




\section{TERRESTRIAL PHOTOVOLTAIC MEASUREMENT PROCEDURES}

Many organizations and individuals are manufacturing and performing research on solar cells and arrays for terrestrial applications in support of both the Energy Research and Development Administration's National Photovoltaic Program and other various organizations. With so many organizations and individuals either manufacturing or doing research on solar celis

fo: terrestrial applications, there is a need for a set of standard test procedures. These procedures would afford a common basis for comparing solar cells and also provide data for the design of large arrays. An interim manual was issued in Juiy 1975 (ref. 1) by ERDA and the National Aeronautics and Space Administration (NASA) as a result of the ERDA/NASA Workshop on Terrestrial Photovoltaic Measurements held on March 19-21, 1975, in Cleveland, Ohio. A second workshop was held on November 10-12, 1976, at Baton Rouge, Louisiana. This manual incorporates approved revisions resulting from the ERDA/NASA 1976 Workshop.

This manual includes procedures for obtaining cell and array currentvoltage measurements both outdoors in natural sunlight and indoors in simulated sunlight, a description of the necessary apparatus and equipment, the calibration and use of reference solar cells, soine comments relating to concentration cell measurements, and a revised terrestrial solar spectrum for use in theoretical calculations.

\subsection{DEFINITIONS}

The following terms are used throughout the procedures:

(1) Reference solar cell - a cell made from the same material as the test cell/array and used to set simulator irradiance levels (The reference cell is provided by the central testing laboratory or is directly traceable to it. It is calibrated in units of short-circuit current output per unit of radiant energy input $\left(A /\left(W / m^{2}\right)\right.$.) 
(2) Standard test conditions (STC) . cell temperature, $28^{\circ} \pm 2^{0} \mathrm{C}$; irradiance, $1000 \mathrm{~W} / \mathrm{m}^{2}$ as measured with reference cell

(3) Short-circuit current $\left(I_{s c}\right)$ - the current through a precision load resistor such that the voltage across the cell/array is less than $20 \mathrm{mV}$ per junction

(4) Open-circuit voltage $\left(V_{o c}\right)$ - the voltage across the unloaded (open) cell/array measured with a voltmeter having an internal resistance of at least $20 \mathrm{k} \Omega / \mathrm{V}$

(5) Miximum power - the power at the point on the current-voltage curve where the current-voltage product is a maximum

(6) Rated power - the power at a specified voltage

(7) Test cell area - the entire front surface area of the cell, including area covered by grids and contacts (For concentrator cells, test cell area is the area designed to be illuminated. )

(8) Module - smallest independent unit consisting of two or more interconnected cells

(9) Subarray - a specified size grouping of modules

(10) Array - a grouping of subarrays required for the particular application (Throughout the remainder of this manual, the term array will mean module, subarray, or array.)

(11) Array area - the entire frontal area including borders and frame

(12) Fill factor (FF) - the ratio of maximum power output of the cell/array to the product of open-circuit voltage and short-circuit current:

$$
F F=\frac{\text { Maximum power }}{V_{\text {oc }} I_{s c}}
$$

(13) Efficiency - the ratio of the maximum power output to the product of area and incident irradiance:

$$
\text { Eff }(\%)=\left(\frac{\text { Maximum power }}{\text { Area } \times \text { Irradiance }}\right) \times 100
$$

As an aid in understanding the measurement procedures in this document, figure 1 shows a block diagram of the different types of measuremnnt methods. 
The details of these methods are presented in subsequent sections of this document.

\subsection{NATURAL SUNLIGHT MEASUREMENT PROCEDURES}

The only accepted testing method for outdoor measurement of solar cells or arrays is the reference cell method. The reference standard to be employed for determining intensity in this method is a calibrated photovoltaic cell obtained from the recognized calibration facility (NASA Lewis Research Center, Cleveland, Ohio) or traceable to that facility. The reference cell must be supplied with a certificate of calibration indicating sensitivity. The calibration conditions for this cell are described in section 5 . The reference cell must be made from the same type of material and have essentially the same spectral response characteristic as the cells or array of cells being tested.

\subsection{Measurement Equipment}

The following measurement equipment is used in the natural sunlight procedure.

(1) Reference cell: The intensity of natural sunlight is determined by the reference cell described previously and in section 5 .

(2) Reference cell readout: The output of the reference solar cell is measured with equipment which meets the requirements described in section 6. 2 .

(3) Temperature monitoring and control: The monitoring and control of reference cell temperature must be in accordance with the specifications given in section 6.2. The temperature of all cells or arrays being tested must be measured to the same accuracy. For large arrays, cell temperatures should be monitored at a number of locations, with not less than 2 sensors per square meter of surface area.

(4) Alinement: The surfaces of the reference cell and the cell or array being tested must be maintained perpendicular to the direct solar beam throughout the test.

(5) Test cell fixture: The solar cell to be tested is mounted on a test 
fixture which meets the requirements set forth in section 6.2. If an array of cells is being tested, array mounting and temperature control are at the option of the investigator. However, the actual temperature of the array must be reported, and four wire measurement techniques shall be employed insofar as possible.

(6) Test cell and array performance measurement equipment: The performance of the test cell or array is measured by using equipment which meets the requirements set forth in section 6.2 .

\section{2 Measurement Procedures}

The reference cell and the cell (or array) to be tested are alined perpendicular to the Sun. The reference cell is coplanar with the test cell(s). The test location must be such that the entire cell or array and the reference cell are fully and uniformly illuminated. The surrounding area must be free of any highly reflective surfaces which would be capable of significantly increasing the solar and celestial radiation onto the cell or array. For work at low solar elevations (high zenith angles) the foreground should be dark (e.g., dark earth or blacktop). Highly reflective materials, even such natural materials as bright sand, must not be on the surface in the foreground.

The current-voltage (I-V) characteristi: of the cell (or array) being tested is recorded at ine same time as the output of the reference cell. The solar intensity as measured by the output of the reference cell must remain constant within 0.5 percent during measurement and must be at least $800 \mathrm{~W} / \mathrm{m}^{2}$.

Normally, during outdoor measurements the solar irradiance is not exactly $1000 \mathrm{~W} / \mathrm{m}^{2}$ and, unless controlled, the array cell te mperature is not $28^{\circ} \pm 2^{\circ} \mathrm{C}$. If translation of the measured $\mathrm{I}-\mathrm{V}$ curve to slandard test conditions (STC $-1000 \mathrm{~W} / \mathrm{m}^{2}$ and $28^{\circ} \mathrm{C}$ ) is desired, the foi owing equations may be used (ref. 2):

$$
\Delta \mathrm{I}=\mathrm{I}_{\mathrm{sc}}\left(\frac{\mathrm{J}_{2}}{\mathrm{~J}_{1}}-1\right)+\alpha\left(\mathrm{T}_{2}-\mathrm{T}_{1}\right) \mathrm{A}
$$




$$
\begin{gathered}
\mathrm{I}_{2}=\mathrm{I}_{1}+\Delta \mathrm{I} \\
\mathrm{V}_{2}=\mathrm{V}_{1}+\beta\left(\mathrm{T}_{2}-\mathrm{T}_{1}\right)-\Delta \mathrm{IR} \mathrm{R}_{\mathrm{s}}-\mathrm{K}\left(\mathrm{T}_{2}-\mathrm{T}_{1}\right) \mathrm{I}_{2}
\end{gathered}
$$

where $I_{2}, V_{2}, J_{2}$, and $T_{2}$ are current, voltage, irradiance, and temperature at STC; $\mathrm{I}_{1}, \mathrm{~V}_{1}, \mathrm{~J}_{1}$, and $\mathrm{T}_{1}$ are the measured values; $\alpha$ and $\beta$ are the current and voltage temperature coefficients ( $\beta$ is negative); $R_{S}$ is series resistance; $K$ is a curve correction factor; and $A$ is area. The $R_{S}$ and $\mathrm{K}$ values must be obtained from experimental determination.

On warm days, where the uncontrolled cell or array temperature may get very high, it may be advantageous to shadow the test cell or array. Prior to measurement, the shadow is removed and data are taken quickly while the cell or array is close to ambient temperature.

\subsection{INDOOR MEASUREMENT PROCEDURES}

There are two test methods for the indoor measurement of cells and array. The first uses a steady-state solar simulator while the second uses a pulsed light (milliseconds) solar simulator. Both methods require a reference solar cell for intensity adjustmc nt ir measurement.

\subsection{Measurement Equip ment}

The following test equipment is used in the indoor measurement procedures:

(1) Refereace solar cell: The light intensity is adjusted or measured by using a reference cell which meets the specification described in section 5 .

(2) Light source: The light source for the solar simulator is either a short-arc or long-arc xenon lamp or a dichroic filtered tungsten la mp. The simulator must meet the specificaticns of 6.1 .

(3) Reference solar cell readnut: The output of the reference solar cell is measured by using equipment $w_{1}$ ich meets the requirement described in section 6.2.

(4) Temperature monitoring and control (steady-state): The temperatures 
of the test cell and the reference cell are monitored and controlled as described in section 6.2. The test cell temperature must be maintained at $28^{\circ}-2^{\circ} \mathrm{C}$.

(5) Test cell fixture (steady-state): The solar cell to be tested is mounted on a fixture which meets the requirements set forth in section 6.2. This test cell fixture may also be interchangeable with the reference cell.

(6) Test cell or array measurement equipment: The performance of the test cell or array is measured by using equipment which meets the requirements set forth in section 6.2 .

\subsection{Measurement Procedures}

Steady-state method. - The light source is turned on and stabilized. The light source intensity is adjusted to $1000 \mathrm{~W} / \mathrm{m}^{2}$ as determined by measuring the short-circuit current of a calibrated reference solar cell held at a temperature of $28^{\circ} \pm 2^{\circ} \mathrm{C}$. The reference cell is replaced with a test fixture that is temperature controlled. The cell temperature is set to $28^{\circ} \pm 2^{\circ} \mathrm{C}$ by using a cummy solar cell with a thermocouple attached to the top of the cell. The cell to be measured is placed in the test fixture, and the output is measured with four terminal contacts and appropriate $r$ adout equipment.

Pulsed method. - The procedures supplied by the pulsed simulator manufacturer are to be followed. The temperature of the test cell or array is measured and entered into the pulsed simulator data system. If a large number of cells or arrays are to be measured, and they are all at room temperature, then only an occasional temperature measurement is necessary. The reference cell and test cell or array are mounted coplanar and perpendicular to the pulsed beam. Care must be taken to ensure that the reference cell is included in a portion of the pulsed beam that meets the nonuniformity specification of section 6.1 .

\subsection{CONCENTRATOR SYSTEM MEASUREMENTS PROCEDURES}

The measurement and characterization procedures to be used for solar cells intended for concentrator systems are to follow the procedures for 
conventional cells in sections 2 and 3 with the added consideration that the intensity of solar irradiance is to be treated as a variable. The following additional points are to be considered:

(1) The cell performance and system performance are to be measured separately.

(2) The efficiency of a concentrator cell must use the cell area designed to be illuminated by the concentrator.

(3) The temperature of the cell junction must be maintained at $28^{\circ} \pm 2^{\circ} \mathrm{C}$.

(4) The nonuniformity of irradiance in the test plane must be less than \pm 20 percent. (This tolerance value is temporary until the effect of nonuniform irradiance on a concentrator cell is more fully understood.)

(5) The angle of incidence of concentrated irradiance on the cell must be within a full angle of $60^{\circ}$ (cone half-angle of 30 percent).

\section{0 CALIBRATION OF REFERENCE CELLS}

In order to make accurate performance measurements on solar cells under a variety of light sources, it is necessary that calibrated reference solar cells be available to set or measure intensity. This section describes the procedure to be used for calibrating these 5 lar cell references under natural sunlight. (This calibration of reference cells is performed by NASA Lewis Research Center only and is included in this manual for information purposes.)

\subsection{Measurement Equipment}

The following measurement equipment is needed in the calibration of solar cells:

(1) Cell holder: The cell to be calibrated is mounted in a hermetically sealed container. The holder must be capable of being cooled or heated and a thermocouple or ther mistor provided for temperacure monitoring. Four output terminals (voltage + and -; current + and -) shall be provided.

(2) Irradiance monitor: Sunlight irradiance is measured by using a normal-incidence pyrheliometer (NIP). The reference cell being tested must 
have the same field of view as the NIP ( $5^{\circ} 42^{\prime}$ full angle). The Sun must be tracked within $\pm 0.5^{\circ}$ during testing. The NIP is calibrated under the absolvtr cavity radiometric scale (PACRAD III).

(3) Test cell measurement equipment: The readout equipment specifications are given in section 6.2.

\section{2 Calibration Procedures}

The calibration of solar cells is performed in natural sunlight under the following conditions:

(i) Intensity: The direct beam sunlight irradiance must be between $\mathbf{7 5 0}$ and $900 \mathrm{~W} / \mathrm{m}^{2}$ at the time of the test, as measured by the NIP.

(2) Intensity stability: The atmospheric conditions must be sufficiently stable so that the variation in cell current is less than \pm 0.5 percent during any 30-second measurement period.

(3) Clouds and haze: The sky must be clear and blue with no observable cloud formations within a $15^{\circ}$ half-angle cone surrounding the Sun.

(4) Turbidity: The product of optical air mass and atmospheric turbidity during measurement must be less than 0.25 (turbidity determined from measurements at $500 \mathrm{~nm}$ ). As an alternate, the ratio of uncollimated to collimated short-circuit current (using the NIP collimation angie) must be less than 1.2.

(5) Air mass: The optical air mass between the test cell and the Sun must be between 1 and 2. Cell temperature must be maintained a: $28^{\circ} \pm 2^{\circ} \mathrm{C}$ during measurement. Adequate measurement of cell spectral response is necessary to characterize cell type insofar as possible. Calibration values are reported as $A /\left(W / m^{2}\right)$ and are adjusted to the following atmospheric conditions:

Precipitable water vapor, $\mathrm{cm} \ldots \ldots \ldots$

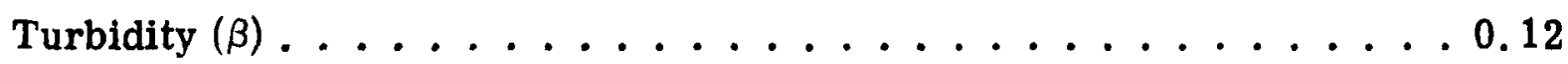

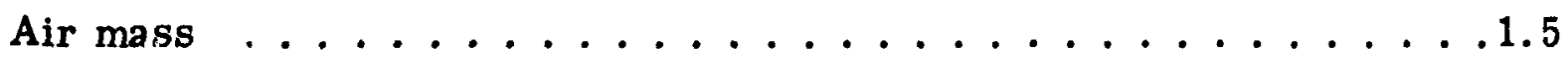

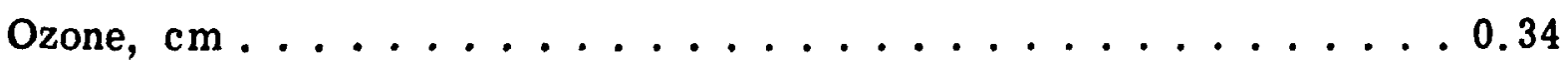

Calibration values must be result of at least three measurements on 
two different days. Short-circuit current neasurements must be made with a 0.1 -percent precision resistor at a voltage less than $20 \mathrm{mV}$ across the cell.

It should be noted that the previous calibration procedure is based only on the normal incidence pyrheliometer. Another method uses a wide-angle detector (global method). But due to lack of correlation data, the NIP method is the only one currently used.

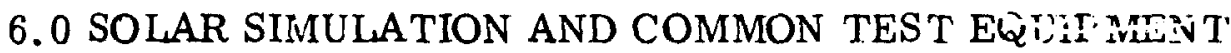

\subsection{Solar mulator for Photovoltaic Measure ments}

There are three acceptable light sources for solar simulators used in terrestrial photovoltaic measurements: a short-arc steady-state xenon lamp, a long-arc pulsed xenon lamp, or a dichrc_c filtered tungsten lamp (ELH type). The source is modified by optics and filters to meet the requirement listed here. These three light sources all have reasonable spectral matches to terrestrial sunlight.

The sunlight simulator should have the foilowing characteristics:

(1) Total irradiance: The simulator must be capable of at least 1000 $\mathrm{W} / \mathrm{m}^{2}$ as measured with a reference solar cell matched to the array or cells to le tested.

(2) Nonuniformity of total irradiance: Nonuniformity of total irradianc 2 is defined (in percent) as

$$
\left(\frac{\text { Maximum }}{2 \times \text { Avradiance }- \text { Minimum irradiance }}\right) \times 100
$$

where the maximum and minimum irradiances are in the plane of the test cell or array. The area of the detectur must be less thar one-quarter of the test call area or, for the case of ribbon cells, the largest dimension of the detector must be less than one-half of the smallest dimension of the cell being measured. Nonuniformity of total irradiance should be less than 2 percent.

(3) Temporal stability of irradiance: The temporal stability is defined in a similar manner to the nonuniformity of total irradiance. It nust be within 


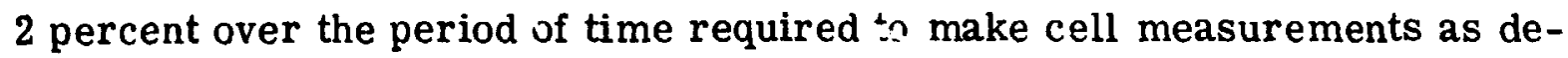
termined by a solar cell detector.

(4) Solar beam subtense angle: The angle subtended by the apparent sour:e of the simulator on a point on the test cell must be less than $30^{\circ}$.

\subsection{Common Test Equipment}

Most of the solar cell tests described previously require essentially identical equipment. The details and specifications of this equipment are listed here.

Reference solar cell readout. - A digital voltmeter, potentiometric recorder, or other suitable measuring instrument capable of measuring with an error less than \pm 0.5 percent over the 0 to $100 \mathrm{mV}$ range is used to measure reference cell output. If preamplifiers are used to match an automatic data system level, the system must meet the less than \pm 05 percent error requirement as demonstrated by impressing known voltages across an input impedance equal to that of the standard cell device.

Temperature monitnring and control. - Each reference cell holder is fitted with a suitable thermocoliple or thermistor, which is used to set temperature at standard conditions. With this sensor the measuring equipment must be capable of $1^{\circ} \mathrm{C}$ : "uacy. Reference coll temperature is to be maintained at $28^{\circ} \pm 2^{\circ} \mathrm{C}$.

Test _xture (steady state). - The solar cell to be tested is mounted on a test fixture which has the following features: vacuum holdduwn, temperaturecontrolled block, and four terminal contacts (current + and -; voltage + and $-)$.

Cell and array measurement equipment. - Equipment must be capable of measuring the voltage and current of the solar cell over the range between open-circuil voltage and short-circuit current with an error less than 0.5 percent. Shor-circuit current must be measured at a voltage less than $20 \mathrm{mV}$ per junction. Open-circuit voltage is measured with: meter having an iniernal resista tce of at least $20 \mathrm{k} \Omega / \mathrm{V}$. Instruments such as digital voltmeters and $\mathrm{X}-\mathrm{Y}$ plotters shall have calibrations which can be traced to a recognized standard. 


\subsection{TERRESTRLAL SOLAR SP ECTRUM}

For purposes of theoretical calculations, a revised terrestrial so'zr spectrum is provided (see fig. 2). Table I gives the spectral irradiance data in $W / \mathrm{cm}^{2}-\mu \mathrm{m}$ for corresponding wavelengths. Also given in table $I$ are the average number of photons $/ \mathrm{cm}^{2}$-sec for wavelength intervals between the corresponding wavelength and the one above it. This spectral distribution of the direct solar beam was calculated using a computer prograu. supplied by Dr. M. Thekaekara. The model starts with an AMO spectrum and attenuates for various scattering and absorbing processes. The model was revised slightly to allow forward scattering by aerosols. This was done by increasing the transmission of the turbidity term by one-half of the difference between 100 percent and the uncorrected turbidity term. The parameters used in converting the Labs and Neckel AMO data to terrestrial spectrum are as follows:

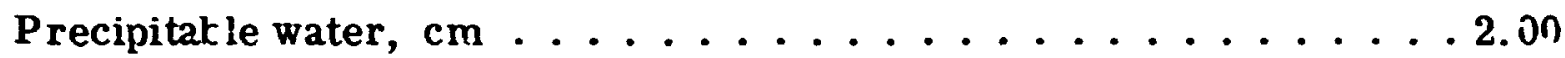

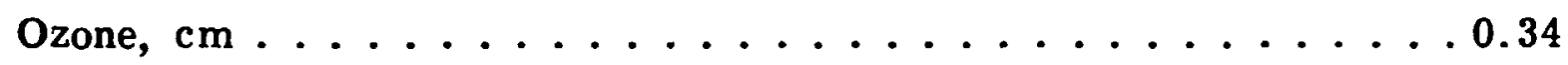

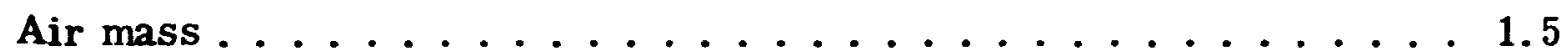
Aerosol scattering parameters:

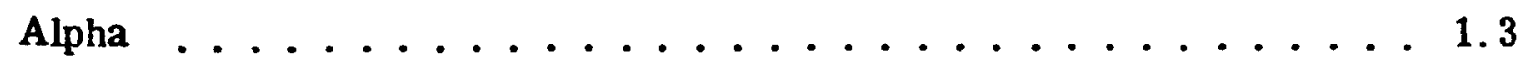

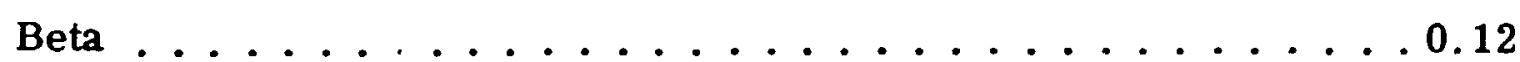

\section{REFERENCES}

1. Brandhorst, Henry W., Jr., et al.: Interim Solar Cell Testing Procedures for Terrestrial Applications. NASA TM X-71771, 1975.

2. Sandstrom, J. D.: A Method for Predicting Solar Cell Current-Voliage Characteristics as a Function of Incident Solar Intensity and Cell Temperature. Sixth Photovoltaic Specialists Conference, vol. II, Inst. Elect. Electron. Eng., 1967, pp. 199-208. 
TABLE 1. - REVEED AIR-MASS-1. 5 SPECTRAL DSTRBUTION

\begin{tabular}{|c|c|c|c|c|c|}
\hline $\begin{array}{c}\text { Wave- } \\
\text { length, } \\
\mu \mathrm{m}\end{array}$ & $\begin{array}{l}\text { Irradinnce, } \\
w^{\prime}\left(\mathrm{em}^{2}-\mu \mathrm{m}\right)\end{array}$ & $\begin{array}{c}\text { (Number of } \\
\left.\text { photwas)/(sec-c } \mathrm{cm}^{2}\right)^{\mathrm{n}}\end{array}$ & $\begin{array}{c}\text { Wave- } \\
\text { length, } \\
\mu \mathrm{m}\end{array}$ & $\begin{array}{c}\text { Irradiance, } \\
w /\left(\mathrm{cm}^{2}-\mu \mathrm{m}\right)\end{array}$ & $\begin{array}{c}\text { (Number of } \\
\left.\text { photons)/(aec }-\mathrm{cm}^{2}\right)^{2}\end{array}$ \\
\hline 0.205 & 0 & 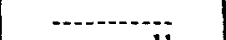 & 0.900 & 807.83 & $4.5747 \times 10^{15}$ \\
\hline .305 & 1.32 & $4.9792 \times 10^{11}$ & .9075 & 793.87 & 2. $7358 \times 10^{15}$ \\
\hline .315 & 20.96 & 1. $7405 \times 10^{13}$ & .915 & 778.97 & $2.7088 \times 10^{15}$ \\
\hline .325 & 113.48 & $1.0841 \times 10^{14}$ & .925 & 217.12 & $2.3093 \times 10^{15}$ \\
\hline .335 & 182.23 & $2.4591 \times 10^{14}$ & .930 & 163.72 & $4.4507 \times 10^{14}$ \\
\hline .345 & 204.43 & 3. $5699 \times 10^{14}$ & .940 & 249.12 & $9.7273 \times 10^{14}$ \\
\hline .355 & 286.01 & $4.5903 \times 10^{14}$ & .950 & 201.30 & $1.1441 \times 10^{15}$ \\
\hline .365 & 955.88 & $5.8232 \times 10^{14}$ & .955 & $255 . \div 1$ & $5.8437 \times 10^{14}$ \\
\hline .375 & 386.80 & $6.9247 \times 10^{14}$ & .965 & 279.69 & $1.2950 \times 10^{15}$ \\
\hline .385 & 381.78 & $7.3599 \times 10^{14}$ & .975 & 529.64 & $1.9789 \times 10^{15}$ \\
\hline .395 & 492.18 & 8. $=10^{14}$ & .985 & 496.64 & $2.5345 \times 10^{15}$ \\
\hline .405 & 751.72 & 1. $2539 \times 10^{15}$ & 1.018 & 585.03 & $9.0087 \times 10^{15}$ \\
\hline .415 & 822.45 & $1.6264 \times 10^{15}$ & 1.082 & 486.20 & $1.8141 \times 10^{16}$ \\
\hline .425 & 842.26 & $1.7619 \times 10^{15}$ & 1.094 & 448. 74 & $3.0761 \times 10^{15}$ \\
\hline .435 & 890.55 & 1. $9777 \times 10^{15}$ & 1.098 & 186.72 & $1.0335 \times 10^{15}$ \\
\hline .445 & 1077.07 & 2. $1817 \times 10^{15}$ & 1.101 & 500.57 & 8. $2066 \times 10^{14}$ \\
\hline .45 & 1162.45 & 2. $5395 \times 10^{15}$ & $1 .: 28$ & 100.86 & $4.5607 \times 10^{15}$ \\
\hline .465 & 1180.61 & $2.7161 \times 10^{15}$ & 1.131 & 1.6 .87 & $1.8592 \times 1 C^{14}$ \\
\hline .475 & 1212.72 & $2.8347 \times 10^{15}$ & 1.137 & 108.68 & $3.8673 \times 10^{14}$ \\
\hline .485 & 1180.43 & .. $8948 \times 10^{15}$ & 1. 14 & 155.44 & $5.3137 \times 10^{14}$ \\
\hline .495 & 1253.83 & $3.0058 \times 10^{15}$ & 1.147 & 139.19 & $2.5515 \times 10^{14}$ \\
\hline .505 & 1242.28 & $3.1451 \times 10^{15}$ & 1.178 & 374.29 & $4.6631 \times 10^{15}$ \\
\hline .515 & 1211.01 & $3.1530 \times 10^{15}$ & 1.189 & 383.37 & 2. $4856 \times 10^{15}$ \\
\hline .525 & 1244.87 & $3.2182 \times 10^{15}$ & 1.193 & 424.85 & 9. $7029 \times 10^{14}$ \\
\hline .535 & 1299.51 & $3.3983 \times 10^{15}$ & 1. 222 & 382.57 & $7.1350 \times 10^{15}$ \\
\hline .545 & 1273.47 & $3.5013 \times 10^{15}$ & 1.236 & 383.81 & $3.3230 \times 10^{15}$ \\
\hline .555 & 1276.14 & $3.5338 \times 10^{15}$ & 1.264 & 323.88 & $6.2418 \times 10^{15}$ \\
\hline .565 & 1277.74 & $3.6040 \times 10^{15}$ & 1.276 & 344.11 & $2.5054 \times 10^{15}$ \\
\hline .575 & 1292.51 & $3.6919 \times 10^{15}$ & 1.288 & 345.69 & 2. $5742 \times 10^{15}$ \\
\hline .585 & 1284.55 & 3. $7666 \times 10^{15}$ & 1.314 & 234.24 & $5.3696 \times 10^{15}$ \\
\hline .595 & 1262.61 & 3. $7871 \times 10^{15}$ & 1.335 & 175.28 & $3.2209 \times 10^{15}$ \\
\hline .605 & 1261.79 & 3. $8169 \times 10^{15}$ & 1.384 & 2.42 & 2. $9831 \times 10^{15}$ \\
\hline .615 & 1255.43 & $3.8695 \times 10^{15}$ & 1.432 & 30.06 & $5.5317 \times 10^{14}$ \\
\hline .625 & 1240.19 & $3.8992 \times 10^{15}$ & 1.457 & 67.11 & $8.8455 \times 10^{14}$ \\
\hline .635 & 1243.79 & $3.9436 \times 10^{15}$ & 1.472 & 59.89 & $7.0321 \times 10^{14}$ \\
\hline .645 & 1233.96 & $3.9961 \times 10^{15}$ & 1.542 & 240.85 & $7.9947 \times 10^{15}$ \\
\hline .655 & 1188.32 & $3.9677 \times 10^{15}$ & 1.572 & 226.14 & $5.4969 \times 10^{15}$ \\
\hline .665 & 1228.40 & 4. $0195 \times 10^{15}$ & 1.599 & 220.16 & $4.8178 \times 10^{15}$ \\
\hline .675 & 1210.08 & $4.1171 \times 10^{15}$ & 1.608 & 211.76 & $1.5719 \times 10^{15}$ \\
\hline .685 & 1200.72 & $4.1311 \times 10^{15}$ & 1.626 & 211.26 & 3. $1027 \times 1 n^{15}$ \\
\hline .695 & 1181.24 & 4. $141^{8 \times 10^{15}}$ & 1.644 & 201.85 & $3.0638 \times 10^{15}$ \\
\hline .6983 & 973.53 & $1.2483 \times 10^{15}$ & 1.650 & 199,6 & $9.9992 \times 16^{14}$ \\
\hline .700 & 1173.31 & $6.4301 \times 10^{14}$ & 1.676 & 180.50 & $4.1424 \times 10^{15}$ \\
\hline .710 & 1152.70 & $4.1224 \times 10^{15}$ & 1.732 & 161.59 & 8. $2262 \times 10^{15}$ \\
\hline .720 & 1133.83 & $4.1199 \times 10^{15}$ & 1.782 & 136.65 & $6.6025 \times 10^{15}$ \\
\hline .7277 & $9 ? 4.30$ & $2.9610 \times 10^{15}$ & 1.362 & 2.01 & $5.0932 \times 10^{15}$ \\
\hline .730 & 1110.93 & $8.8089 \times 10^{14}$ & 1.955 & 39.43 & ¿. $8535 \times 10^{15}$ \\
\hline .740 & 1086.44 & $4.0700 \times 10^{15}$ & 2.008 & 72.58 & 2. $9543 \times 10^{15}$ \\
\hline .750 & 1070.44 & 4. $493 \times 10^{15}$ & 2.014 & 80.01 & $4.6397 \times 1 c^{14}$ \\
\hline .7621 & 733,08 & $4.1577 \times 10^{15}$ & 2.057 & 72.57 & $3.3654 \times 10^{2}=$ \\
\hline .770 & 1036.01 & $2.6980 \times 10^{15}$ & 2.124 & 70.29 & $5.0424 \times 10^{15}$ \\
\hline .780 & 1018.42 & $4.0123 \times 10^{15}$ & 2.156 & 64.76 & 2. $330^{\prime} \times 10^{15}$ \\
\hline .790 & 1003.58 & $3.9999 \times 10^{15}$ & 2. 201 & 68.29 & $3.2869 \times 10^{15}$ \\
\hline .800 & 988.11 & $3.9902 \times 10^{15}$ & 2. 266 & 62.52 & 4. $7856 \times 10^{15}$ \\
\hline .8059 & 860.28 & $2.2067 \times 15$ & 2.320 & 57.03 & $3.7303 \times 10^{15}$ \\
\hline .825 & 932.74 & $7.0375 \times 10^{15}$ & 2.338 & 53.57 & $1.1684 \times 10^{15}$ \\
\hline .830 & 923.87 & 1. $9358 \times 10^{15}$ & 2.356 & 50.01 & 1. $1027 \times 10^{15}$ \\
\hline .835 & 914.95 & $1.9288 \times 10^{15}$ & 2.388 & 31.93 & $1.5673 \times 10^{15}$ \\
\hline .8465 & 407.11 & $3.2212 \times 10^{15}$ & 2.415 & 28.10 & $9.8088 \times 10^{14}$ \\
\hline .860 & 857.46 & $3.6707 \times 10^{15}$ & 2.453 & 24.96 & $1.2367 \times 10^{15}$ \\
\hline .870 & 843.02 & $3.7067 \times 10^{15}$ & 2.494 & 15.82 & $1.0422-3^{15}$ \\
\hline .875 & 835.10 & $1.8448 \times 10^{15}$ & 2.537 & $\begin{array}{r}2.59 \\
2.59\end{array}$ & $5.01 \times n \cdot 10^{14}$ \\
\hline .8875 & 817.12 & $4.5865 \times 10^{15}$ & & & \\
\hline
\end{tabular}

${ }^{2}$ Number of photons $/\left(\mathrm{sec}-\mathrm{cm}^{2}\right)$ in the wavelength interval between the corresponding waveleng th and the one preceding il. Calculated using the average wavelength and irradiance for each waveleng th interval. 


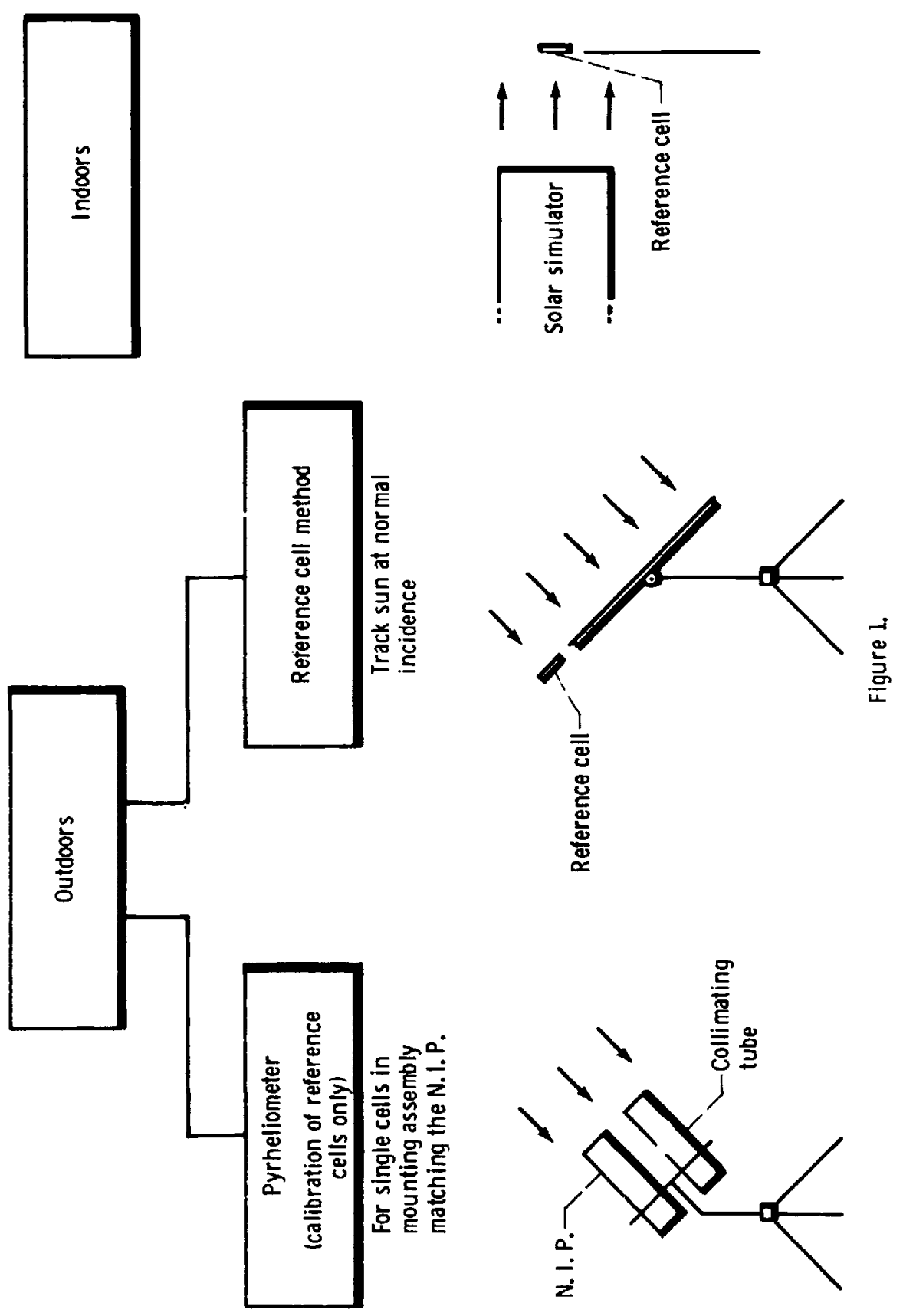




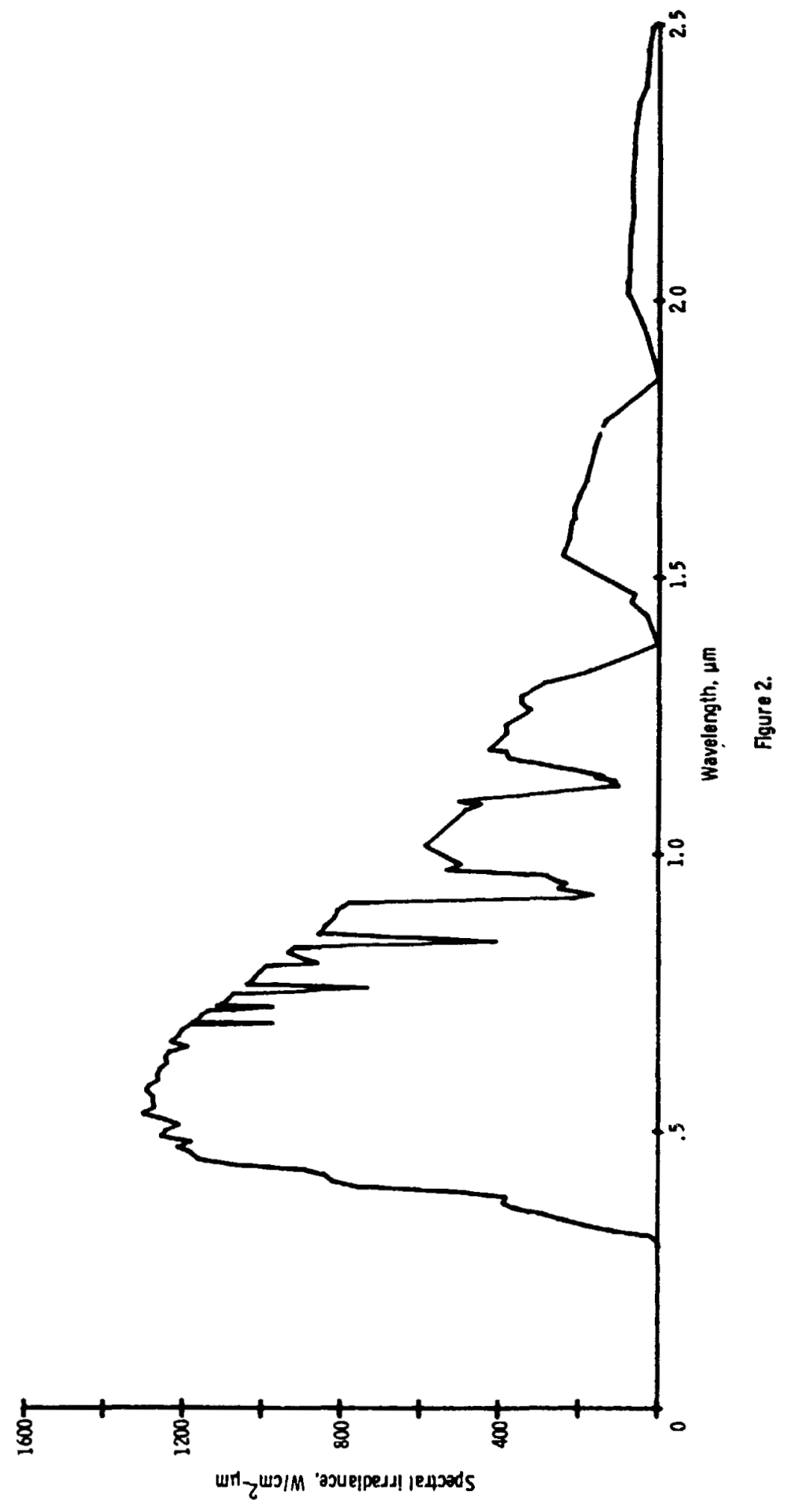




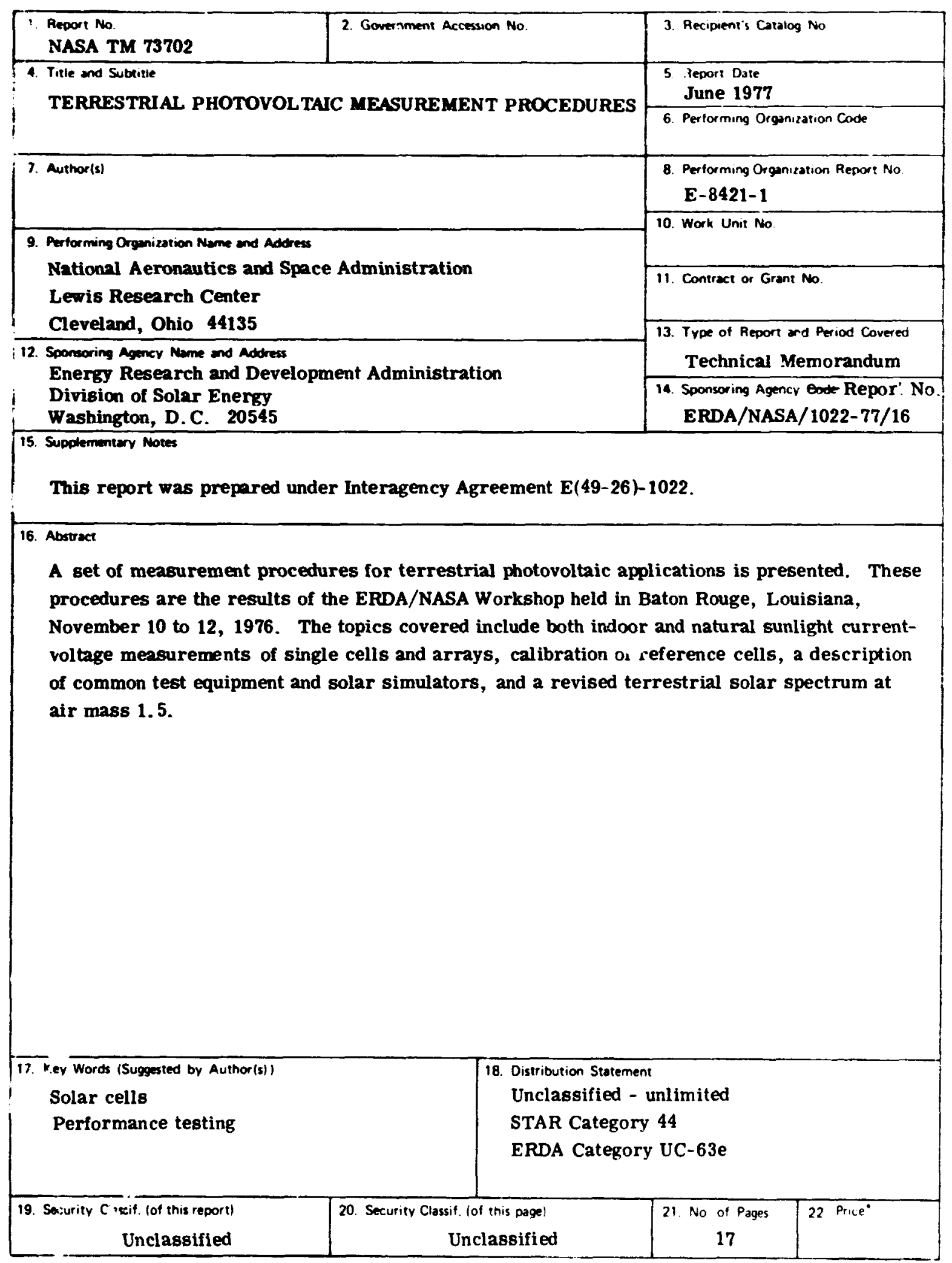

For sale by the National Tectnical Information Service. Springfield Vigina 22161 